\title{
Key factors of employee satisfaction for the retention of health-related professionals in South Africa
}

\author{
Chux Gervase Iwu', Charles O. K. Allen-Ile ${ }^{2}$ and Wilfred I. Ukpere ${ }^{3 *}$ \\ ${ }^{1}$ Department of Entrepreneurship and Business Management, Faculty of Business, Cape Peninsula University of \\ Technology, Republic of South Africa. \\ ${ }^{2}$ Department of Human Resources Management, Faculty of Business, Cape Peninsula University of Technology, \\ Republic of South Africa. \\ ${ }^{3}$ Department of Industrial Psychology and People Management, Faculty of Management, University of Johannesburg, \\ Johannesburg, Republic of South Africa.
}

Accepted 10 July, 2012

\begin{abstract}
The focus of this study is health-related professionals who, according to reports are pushed into other sectors or out of South Africa. Related health professionals refer to laboratory technologists, pharmacists, radiographers, emergency medical services (paramedics), nurses, and optometrists. These practitioners are a diverse group who deliver high quality care to patients across a wide range of care pathways and in a variety of settings. Several reports have been published with regard to employee dissatisfaction within health care profession, unfortunately much of these reports have focused on doctors and nurses without commensurate attention to other health professionals. The central question in this study is: why are there high levels of employee dissatisfaction amongst healthrelated professionals in South Africa? And what remedies are there? This study therefore attempts to understand the factors that will help to reduce the causes of the often acclaimed sense of job insecurity, high levels of health worker absenteeism, and high turnover rates amongst health-related professionals. The findings will possibly help in addressing the difficulty in retaining skilled healthrelated professionals. Data collected was coded for statistical program for social science (SPSS) suitability. SPSS was utilized to generate the frequency and descriptive statistics. Data collection instrument was the Plus Delta Organisational Climate Questionnaire, which was modified on the basis of a preliminary study. The data instrument achieved a coefficient alpha (Cronbach) of 0.9 thus extending its validity. Utilising exploratory factor analysis, the study reveals new factors which are considered central to retaining health-related professionals.
\end{abstract}

Key words: Health-related professions, South Africa, employee dissatisfaction, seven factors of employee satisfaction.

\section{INTRODUCTION}

Research has consistently shown that health establishments face a constant challenge of retaining health professionals. However, the occupational needs of health-related professionals have not been adequately

*Corresponding author. E-mail: iwuc@cput.ac.za
or chuxiwu@gmail.com. investigated. As far back as 1978, Stamps, Piedmont, Slavitt and Haase acknowledged that this had been a common global trend. They add 'Although the health field is not devoid of job satisfaction research, most has concerned hospital nurses... Several studies have focused on turnover rate, either by retrospectively studying nurses who left the hospital, or by comparing the questionnaire responses of nurses who left with those nurses who remained at the hospital. The same can be 
said about South Africa. Most studies (Gilson et al., 2005; Makie, 2006; Mokoka et al., 2010; Pillay, 2009; Smit, 2006; Thomas and Valli, 2006) in South Africa have examined the level of satisfaction of medical doctors and nurses. Luddy (2005) even looked at medical and nonmedical workers in health establishments in Western Cape.

Essentially, the present study focuses on health-related professionals in South Africa with the hope of understanding their practice/occupational needs, so that these needs can be better served. Underserved needs of any type (or even level) of worker can result in a number of unanticipated consequences for any organisation. In the case of health establishments, an unhappy group of health-related professionals can negatively affect the well-being of those who live in the country. Healthcare workers experience major unhealthy challenges in their practice (McCann et al., 2009: 189). These challenges can result in severe distress, burnout or physical illness and to a decrease in quality of life and service provision. When any of these is experienced, it can lead to increased absenteeism and turnover (Grobler et al., 2006; Robbins et al., 2009); while increased absenteeism and turnover can subsequently lead to increased workload, poor response to suffering or dying patients and organisational problems and conflicts (De Witte, 2005; Govender, 2006; Pundit, 2006). Sadly health professionals face challenges such as neglect, lack of attention, malfunctioning equipment, a dissatisfied customer, overwork and many more.

A South African online newsmagazine (INET Bridge, 2012) recently reported that the minister of health in Gauteng was disturbed by the increasing numbers of litigations coming from patients of Gauteng health services who were unhappy with the services they received. During preliminary interaction with members of the health-related profession in pursuance of this study, fear was raised by senior management at the selected institutions that there may not have enough time to complete the research questionnaires. This seems to support the findings of McCann et al. (2009: 192) regarding pharmacists who felt overworked, yet disturbed by incessant phone calls. Health-related professionals comprise a diverse group of practitioners who deliver high quality care to patients across a wide range of care pathways and in a variety of settings. They include nurses, optometrists, radiographers, pharmacists, laboratory technologists/technicians, and emergency medical services.

These highly skilled professionals can be found in both the private and the public sector, while their roles are diverse. They perform essential diagnostic and therapeutic roles, and work across a wide range of locations within acute, primary and community care. They perform functions, which include assessment, diagnosis, emergency care, treatment and discharge throughout the health-care pathway-from primary prevention through to specialist disease management and rehabilitation.
Health-related professionals help to provide a wellrounded team that diagnose and treat patients. If the aforementioned health-related professionals perform such important roles in health care delivery, it does make enormous sense to consider their well-being at work. These bands of professionals should feel valued, appreciated and rewarded. The potential effects of not looking after them will include lowered job performance, withdrawal, and increased absence from duty, counterproductive behaviour and health problems. When these occur, innocent sick people will pay dearly, while health establishments will lose reputation. The aim of health care organisations should, after all, be to improve quality and to build the confidence of patients, professionals and cost payers with regard to the quality of the context, structures, processes, and outcomes (Mosadegh, 2006: 606).

\section{Statement of the research problem}

The focus of this study is health-related professions. Several reports have been published with regard to employee dissatisfaction within health care profession, and these reports point to political instability, economic and social push factors (Kingma, 2001: 205), lack of continued education and professional development (Bundred and Levitt, 2000; Kerse and Ron, 2002). Overseas organisations, as well as well-resourced private establishments seem to be dangling better carrots and, as a result, one finds that there is a high level of job mobility occurring within health professions in South Africa. Unfortunately much of these reports have focused on doctors and nurses without commensurate attention to other health professionals.

\section{Research questions}

The research questions in this study are:

1. Why are there high levels of employee dissatisfaction amongst health-related professionals in South Africa?

2. What remedies are there to solve the problem of employee dissatisfaction amongst health-related professionals in South Africa?

\section{Objectives of the study}

This study attempts to understand the factors that will help to reduce the causes of the often acclaimed sense of job insecurity, high levels of health worker absenteeism, and high turnover rates amongst healthrelated professionals. The findings will possibly help in addressing the difficulty in retaining skilled health-related professionals. 


\section{REVIEW OF LITERATURE}

Marchal and Kegels (2003) assert that discontent was rife amongst South African health professionals while several studies (Luddy, 2005; Makie, 2006; Mariani et al., 2003; Smit, 2006) point out that dissatisfaction amongst South African health-related professionals was high. Many of these professionals have indicated that poor equipment, over-bearing workloads, unsafe working conditions, poor salary and a number of other job content environmental elements are responsible for their dissatisfaction. Many of the dissatisfied would rather leave the country or look for better paid jobs in other fields, or engage in unproductive work behaviours. Mariani et al. (2003) argue that the South African health related professions battle with the challenge of retaining skilled workforce. They report a survey, which was conducted at 79 health clinics in South Africa between November 2002 and February 2003, and projected that $56 \%$ of professional employees intended to go overseas owing to better salary prospects and wanting to further their education. The survey further indicated that $40 \%$ lacked supervision, while $68 \%$ did not receive feedback from supervisors, and $44 \%$ had no job descriptions. Other factors that cause dissatisfaction according to the survey include extra workload, problems with colleagues, stress, employees' shortages, unsafe working conditions and poor equipment.

Thomas and Valli (2006) report that there was an increased tendency on the part of doctors in public sector hospitals in South Africa to see patients in an inanimate light, which suggested that the doctors were overwhelmed with work; a consequence of severe occupational stress. Accordingly, the main sources of pressure at work include understaffing, lack of resources, lack of control, difficult work schedules, inadequate security, and poor career advancement and salaries. Mrara (2010) acknowledges the significance of nurses in health services given that they are 'next' to the patient most of the time. As a result of this, Mrara suggests that in retaining health professionals, health establishments must make them feel that their job is important; provide health professional with comfortable workplace and constant training and development for career enhancement. These Mrara says will increase the efficiency and competitiveness of health establishments.

While health worker personality, past experience, and historical, cultural and socio-political context of the health establishment may influence the level of trust that the health worker may extend to the health establishment, carrying out organisational changes can be one way to gain the confidence of health-related professionals. In the study of the levels of occupational stress in doctors working in a South African public hospital, Thomas and Valli (2006) found that with a new management in the internal medicine department of the hospital that they studied, the medical team began to experience a more consultative and participative process. The work of Gilson et al. (2005: 1426) somewhat gives precedential impetus to Thomas and Valli's study. In their study of the impact of trust on health worker performance in South Africa, Gilson et al. (2005) found that public clinic staff frowned at the lack of engagement with management stressing that the practice of throwing down policies from the top made one not to feel a sense of accomplishment. In De Villiers and De Villiers (2004), a dysfunctional relationship with management was implicated as one of the reasons why doctors hated working in rural hospitals in Western Cape. De Villiers and De Villiers reported that doctors felt ignored because the Western Cape provincial government made decisions in a top-down fashion. This could make doctors feel less valued. Makwetla (2004) mentions that feeling unappreciated and less valued could result in health professionals seeking greener pastures either in other industries or overseas.

Mokoka et al. (2010) suggest the following general factors (including organisational factors) that influence nurses' retention rates: (1) working conditions and hours, (2) professional development opportunities, (3) rewards, (4) relationships at work, (5) workplace safety, (6) availability of resources, and (7) organisational culture and changes. 'In many hospitals in South Africa, support services for nurses are inadequate, often leaving them with no option but try to carry out such work themselves. The inevitable result is that, through no fault of their own, they have to neglect their primary responsibility of caring for their patients. This was the comment of Tshabane (2011), a specialist nursing sister who, at the South African National Nursing Summit in 2011, painted a rather disturbing picture of the state of nursing in South Africa. She was apparently comparing her professional nursing experience in South Africa with a nursing stint she had in Saudi Arabia. She was certainly saying that because of a lack of defined roles and responsibilities, nurses in South Africa were not attending to their primary assignment, which essentially meant taking care of patients. From the foregoing review, one can see that the reasons for the challenge of retaining health professionals and specifically (given the objective of this study) health-related professionals can be located within organisational culture dimensions as well as job satisfaction facets. This study therefore takes a cue from the empirical studies and attempts to understand the various underlying factors which have significant relationship to the issues of health-related professional retention possibility.

\section{RESEARCH METHODOLOGY}

A mixed research approach comprising qualitative, quantitative, exploratory and descriptive research was deployed, given the main objective of the study which was to develop a model of employee satisfaction within health-related professions in South Africa. This approach was considered suitable for a number of reasons including (1) qualitative studies' help to achieve the objective of a study, which has a subjective variable (Malterud, 2001: 483). The concept - satisfaction - is subjective and will, therefore, rely heavily on qualitative analysis (Judge and Locke, 1993; Meeberg, 1993; 
Table 1. The categories and their first reliability statistics.

\begin{tabular}{lcc}
\hline Categories & No. of items & Cronbach's Alpha \\
\hline Organizational design & 5 & 0.754 \\
Individual job characteristics & 5 & 0.826 \\
Co-worker relations & 5 & 0.907 \\
Culture-work environment & 5 & 0.709 \\
Senior management & 5 & 0.631 \\
Work processes & 5 & 0.656 \\
Communication & 5 & 0.552 \\
Technology & 5 & 0.882 \\
${ }^{*}$ Remuneration 1 & 2 & 0.777 \\
${ }^{*}$ Remuneration 2 & 2 & 0.521 \\
\hline${ }^{*}$ Computed together, the category remuneration realized a 0.161 Cronbach alpha, thus necessitating
\end{tabular}
the split.

Sheldon and Bettencourt, 2002); (2) qualitative research assists with careful and systematic collection, ordering, description and interpretation of data (Kitto et al., 2008); (3) qualitative research helps to explore the behaviour, processes of interaction, meanings, values and experiences of purposefully sampled individuals and groups in their natural context (Cronje, 2010; Liamputtong and Ezzy, 2005); (4) quantitative studies' help to obtain reliable frequency and descriptive statistics (Buchanan and Bryman, 2009; Rao, 2010); (5) quantitative research methods aid in the collection of large volumes of data (Taylor, 2009) and in the elimination of factors that are irrelevant in a study (Hopkins, 2007); (6) exploratory studies help to uncover problems, opportunities, threats and salient variables or trends that are located within a research project (Webb, 2002); and (7) given that no study of this nature currently exists within health-related professions in South Africa, exploratory research was considered as suitable because it would assist in gaining greater understanding of the phenomenon under study (Dane, 2011). The findings are presented in descriptive forms using tables and graphs.

\section{Data collection}

To obtain data for this study, a self administered pre-tested questionnaire was utilised. The instrument utilized for data collection was the revised closed-ended Plus Delta Organisational Climate Questionnaire. This instrument was utilized because it is condensed; and according to De Cock (2006), combines facets of job satisfaction with organisational climate dimensions. Questionnaires are popular for studies within the realm of employee satisfaction and have been found to persuade large number of respondents to disclose as much information as possible because it allows for anonymity (Coetzee and Schreuder, 2010; Leong and Austin, 2006; Rao, 2010). Questionnaires are thus helpful in terms of reaching respondents thereby reducing costs that are normally associated with interviews, whether they are conducted one-on-one or via telephone.

The questionnaire comprised 11 categories with a total of 53 items in total. Respondents were asked to rate, using a five-point Likert format on how they found each situation (53 in total). The five-point Likert format ranged from (1) "strongly disagree" to (5) "strongly agree". The categories represented dimensions of organisational climate and job satisfaction facets. The remuneration category contains four (4) items of both negative and positive characters. For instance, two of the items had 'The income I receive is barely enough to provide for my basic needs' and 'The income I receive is adequate for normal expenses'. The other two questions contained 'The income I receive is less than I deserve' and 'The income I receive fits my social standing'. These items were considered appropriate in order to get an idea of how the participants would perceive income (Table 1).

\section{Instrument reliability analysis}

The motivation to adopt the Plus Delta Organisational Climate Questionnaire did not exclude the instrument from a rigorous validity and reliability test. Every research instrument must be assessed prior to use for both validity and reliability purposes (NNSDO, 2005: 1) in order for the instrument to prudently measure what it set out to measure (Coetzee and Schreuder, 2010: 125), and also to lend some credibility to the findings of a study (Welman et al., 2005: 145).

The reliability of the data collection instrument was tested by using the Cronbach Alpha coefficient. Each of the categories was separately tested. An overall reliability analysis of all the categories achieved an acceptable score $(>0.9)$. Given this result, the instrument was deemed sufficient for the study. Previous studies (Van Breda, 2003: 5-7; Chen et al., 2006: 490) state that a reliability coefficient, which exceeds 0.8 for any test or scale, was the minimum acceptable reliability coefficient.

A second reliability analysis of the categories contained in the data collection instrument was conducted. This was done in order to isolate factors or categories on the basis of their reliability/statistical strength. Statistical significance should therefore comprise the ability to identify and possibly direct attention to those factors that significantly enrich a study; in this case, the factors that can guarantee existence and continued performance of healthrelated professionals. In order to achieve these, it was important to make determinations on the degree of reliability that would help perform a meaningful analysis, interpretation and clarity of the results.

There are varying preferences in terms of what constitutes appropriate statistical significance or reliability in any research. Leong and Austin (2006: 107) citing Thorndike (1997) stated that the appropriateness of reliability for a test depended on the purpose of the test. Zikmund et al. (2010: 306) also commented that scales with a coefficient $\alpha$ between 0.80 and 0.95 were considered to have 
Table 2. Second reliability measures of the categories.

\begin{tabular}{lccccc}
\hline Categories & $\begin{array}{c}\text { Reliability } \\
\text { Cronbach's } \\
\text { Alpha }\end{array}$ & $\begin{array}{c}\text { Achieving } \\
\text { desired } \\
\text { Cronbach } \\
\text { Alpha }\end{array}$ & $\begin{array}{c}\text { Reliability } \\
\text { Cronbach's } \\
\text { Alpha }\end{array}$ & $\begin{array}{c}\text { Achieving } \\
\text { desired } \\
\text { Cronbach Alpha }\end{array}$ & $\begin{array}{c}\text { Reliability } \\
\text { Cronbach's } \\
\text { Alpha }\end{array}$ \\
\hline $\begin{array}{l}\text { Organisational design } \\
\text { Individual job characteristics }\end{array}$ & 0.754 & & & & \\
Co-worker relations & 0.826 & & & & \\
Culture/work environment & 0.907 & 0.709 & & & \\
Senior management & 0.67 & Delete v26 & 0.727 & & \\
Direct supervisor & 0.631 & Delete v32 & 0.882 & & \\
Work processes & 0.656 & Delete v36, v39 & 0.66 & & \\
Communications & 0.552 & & & & \\
Technology & 0.882 & & & \\
Customer satisfaction & 0.659 & & & & \\
& & & & \\
Remuneration & 0.609 & V50 and 52 & & & \\
\hline
\end{tabular}

good reliability, while scales with a coefficient $\alpha$ of between 0.70 and 0.80 were considered to have good reliability. They also believed that scales with a coefficient $\alpha$ value of between 0.60 and 0.70 could be said to have fair reliability. In some other studies, 0.50 or more are considered as 'large' reliability (Blaikie, 2003: 111). To this end, the researchers chose to use Zikmund et al. (2010: 306). Therefore, the reliability Cronbach a must be $>0.6$ to achieve minimum coefficient significance. This determination was also made in order to give effect to the critical significance of health-related professionals in any society. In order to identify those factors which are critical to retaining health-related professionals, it was necessary to consider those categories that have reasonably high reliability (in essence indicating those categories and items with very high factor loadings).

Table 2 shows reliability measures of all the categories. The reason for doing this a second time was to abide by the earlier determination - to focus on categories, which have high factor loadings. It is evident from the table, that certain items in the questionnaire were deleted in order to arrive at an acceptable reliability coefficient $\alpha$. According to Blaikie (2003: 220), before applying factor analysis, it is a good idea to inspect the matrix of correlation coefficients. The first thing to do is to see if any item has very low coefficients with all or most of the other items. Such items are not going to find their way into any factor and would be excluded. To achieve a reliable Cronbach $\alpha$ in the category, direct supervisor for instance, the researchers needed to eliminate item 26. The same process was undertaken for the categories Work process (item 32 was deleted) and Communications (items 36 and 39 were deleted). A further interrogation of the category communications realized the exclusion of item 37, which then enabled the achievement of a Cronbach $\alpha$ of 0.768 . Thus, given the objective of the study, elimination of certain items (guided by factor analysis), was deemed necessary.

\section{DATA ANALYSIS AND FINDINGS}

The data that was collected was coded for statistical program for social science (SPSS) suitability. The SPSS was utilized to generate the descriptive statistics, as well as correlation statistics. The descriptive statistics were compiled with the help of frequency tables, while the correlation analysis was done by using a combination of factor analysis, analysis of variance (ANOVA) and T-test.

\section{Participants' demographics}

The participants comprised laboratory technicians, optometrists, radiographers, emergency medical services personnel (specifically paramedics), pharmacists and nurses who work in both the private and public sectors of selected institutions within Cape metropole of Western Province. A total of 62 of the respondents are males, which represent $53 \%$ of the sample, while $47 \%$ are females $(n=55)$ (Figure 1). A total of $50.4 \%$ of respondents were between 41 to 50 years old, while only $6.8 \%$ were between 21 to 30 years. Thirty eight members of the sample were between 31 to 40 years old, while only $10.3 \%$ were between 51 to 60 years old (Figure 2 ).

With regard to marital status, $75.2 \%$ were married, while 16 and 13 members of the sample were single and separated, respectively (Figure 3 ). Respondents who earned between R201, 000 to R300, 000 represented $79.5 \%$ of respondents, while only 1.7 earned between $\mathrm{R} 101,000$ to R200, 000 and R401, 000 to R500, 000, respectively (Figure 4). Africans represented $19.7 \%$ of the sample, while there were 30 Coloureds, $9.4 \%$ of Indians, and $0.9 \%$ of Asians and other ethnic groups, respectively. A majority of respondents are Whites, which represent $43.6 \%$ or 51 members of the sample (Figure 5). Those who have academic qualifications above a 
Iwu et al. 10491

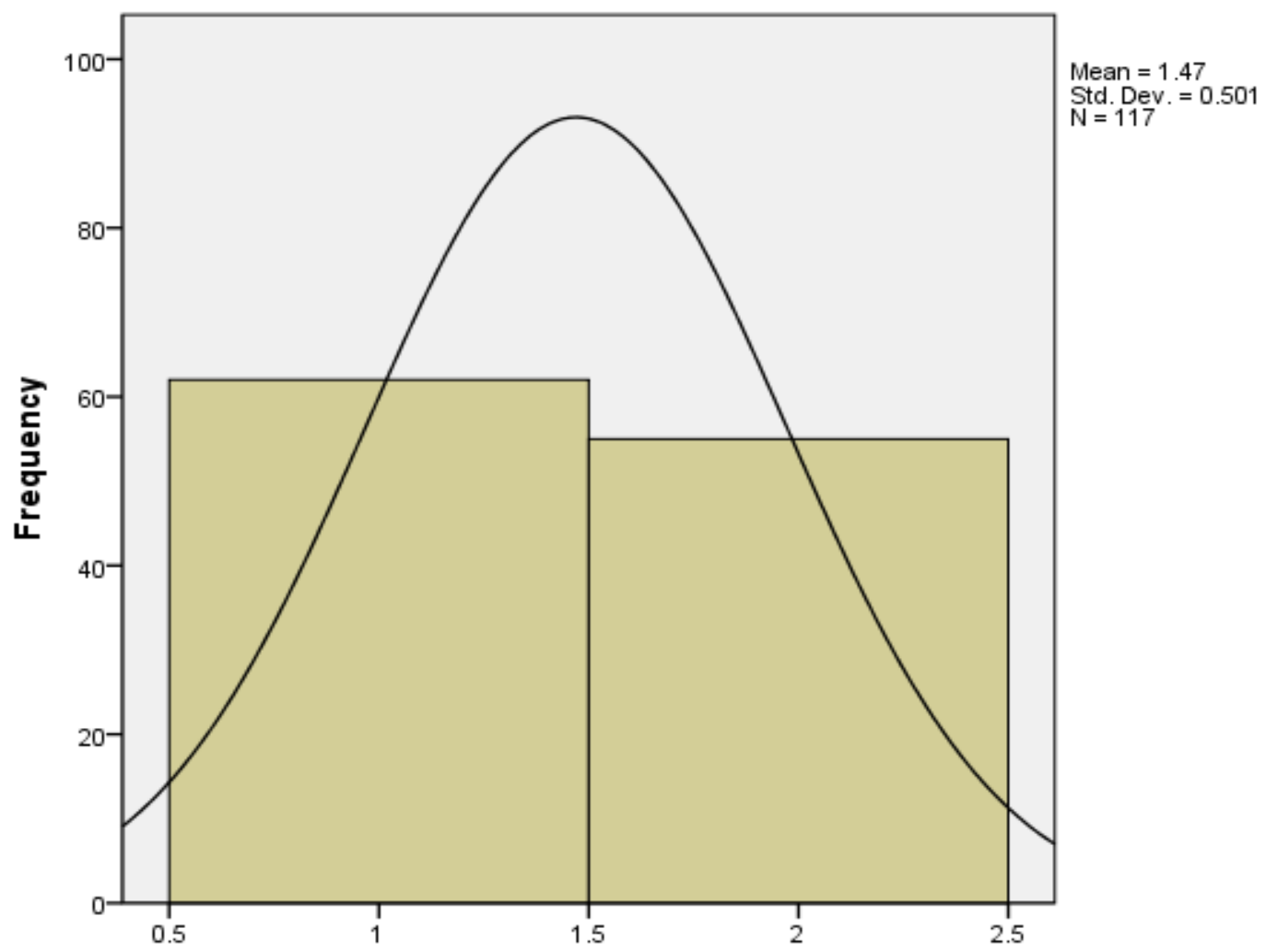

Figure 1. Gender of respondent.

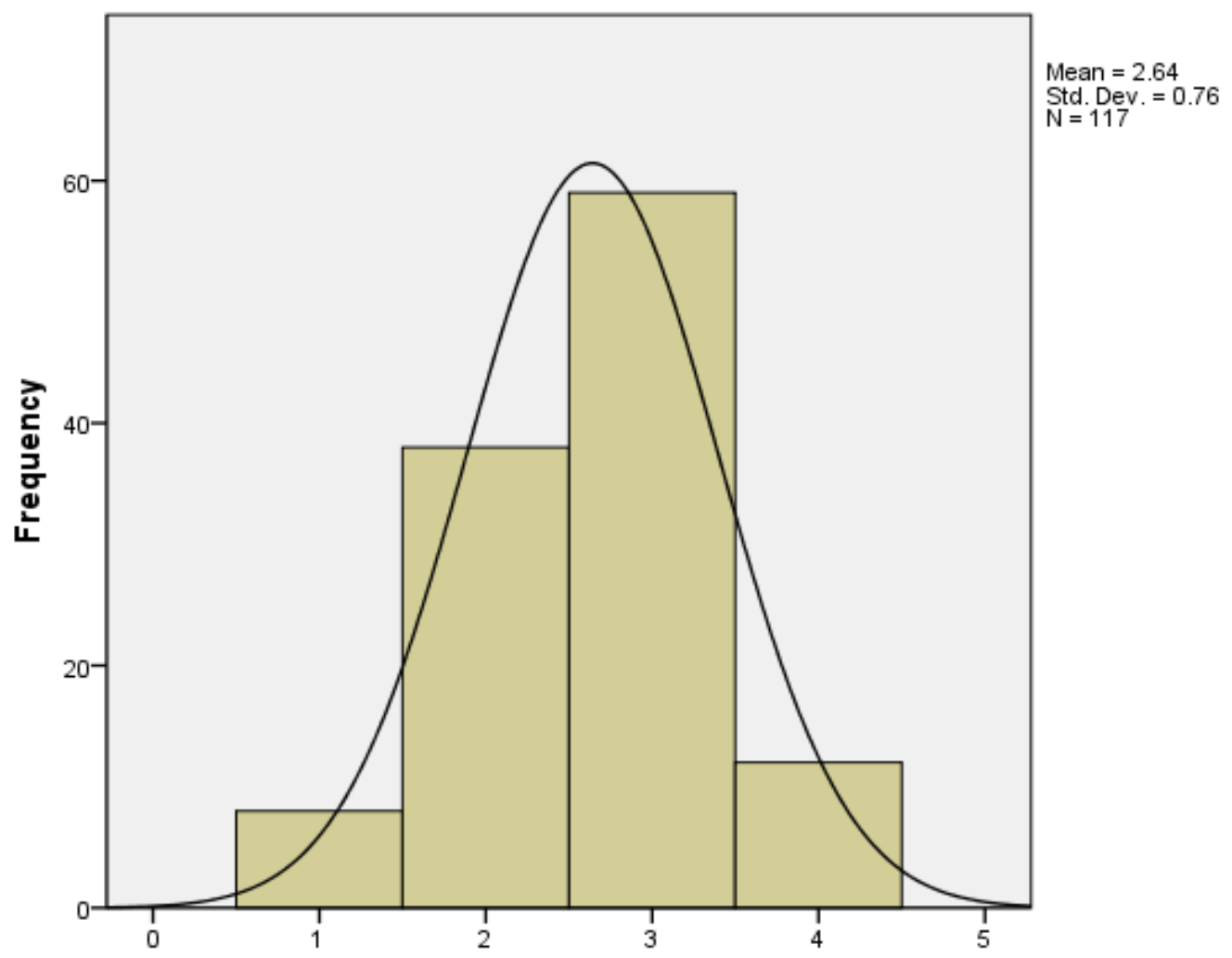

Figure 2. Age of respondent. 


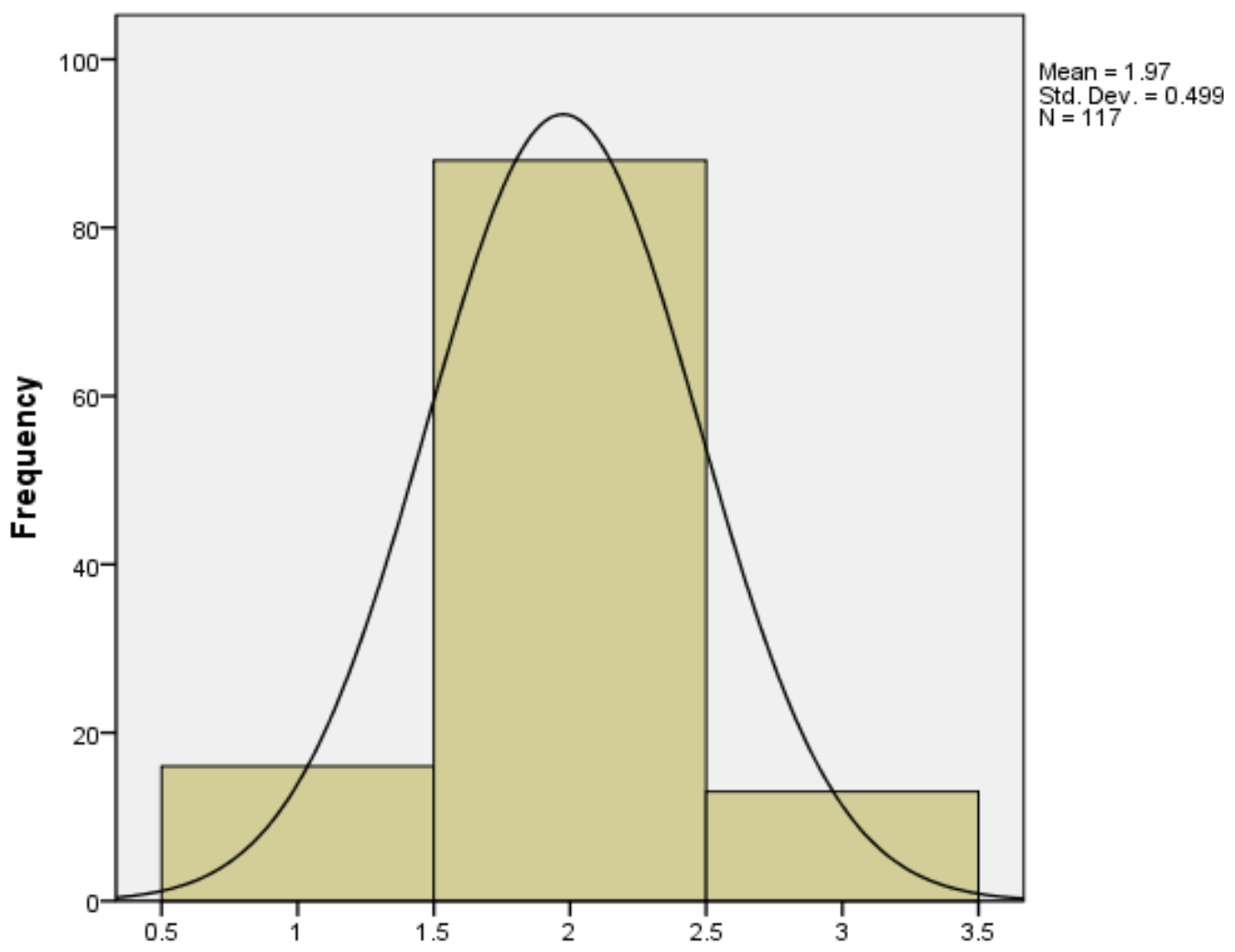

Figure 3. Marital status of sample.

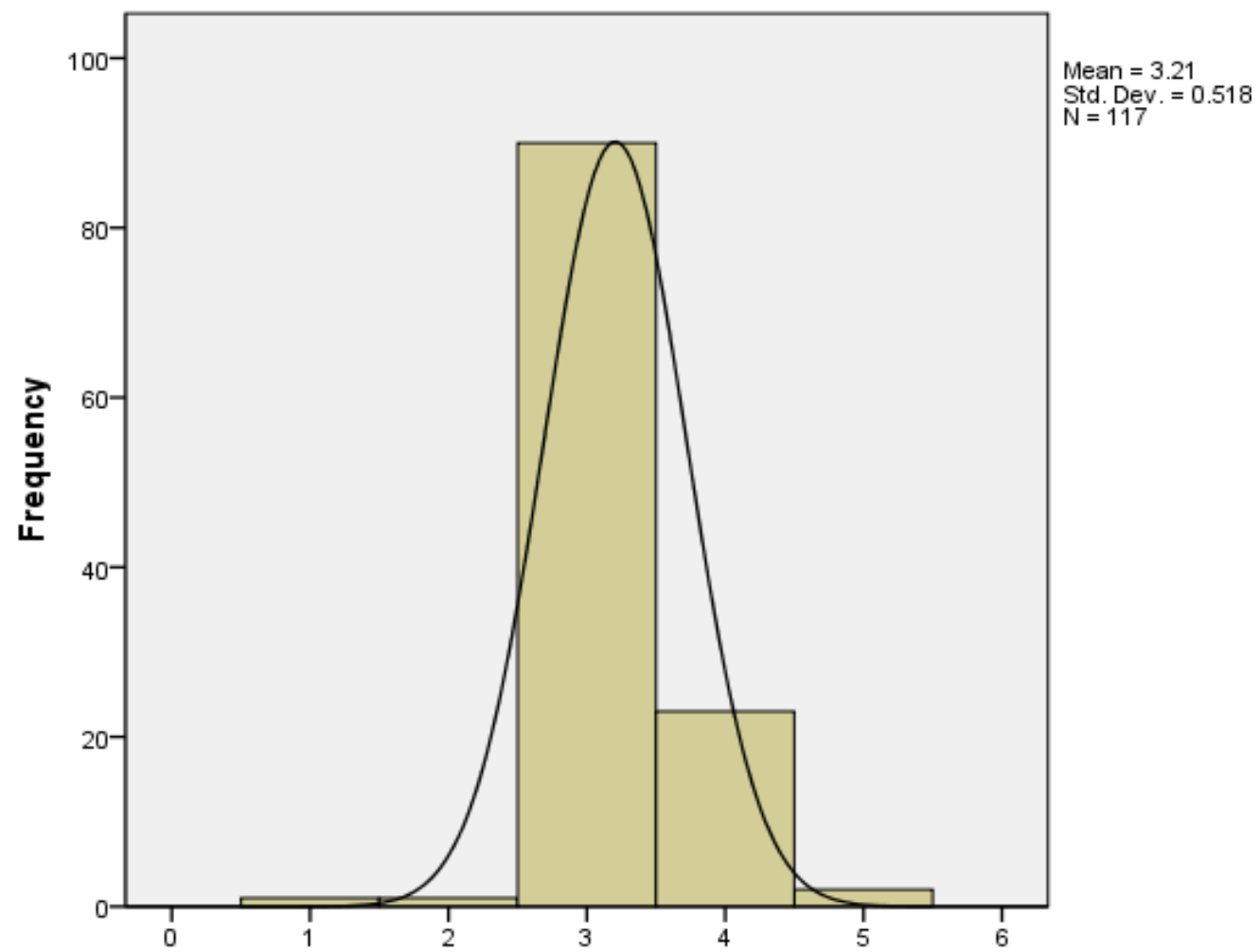

Figure 4. Annual income of sample. 


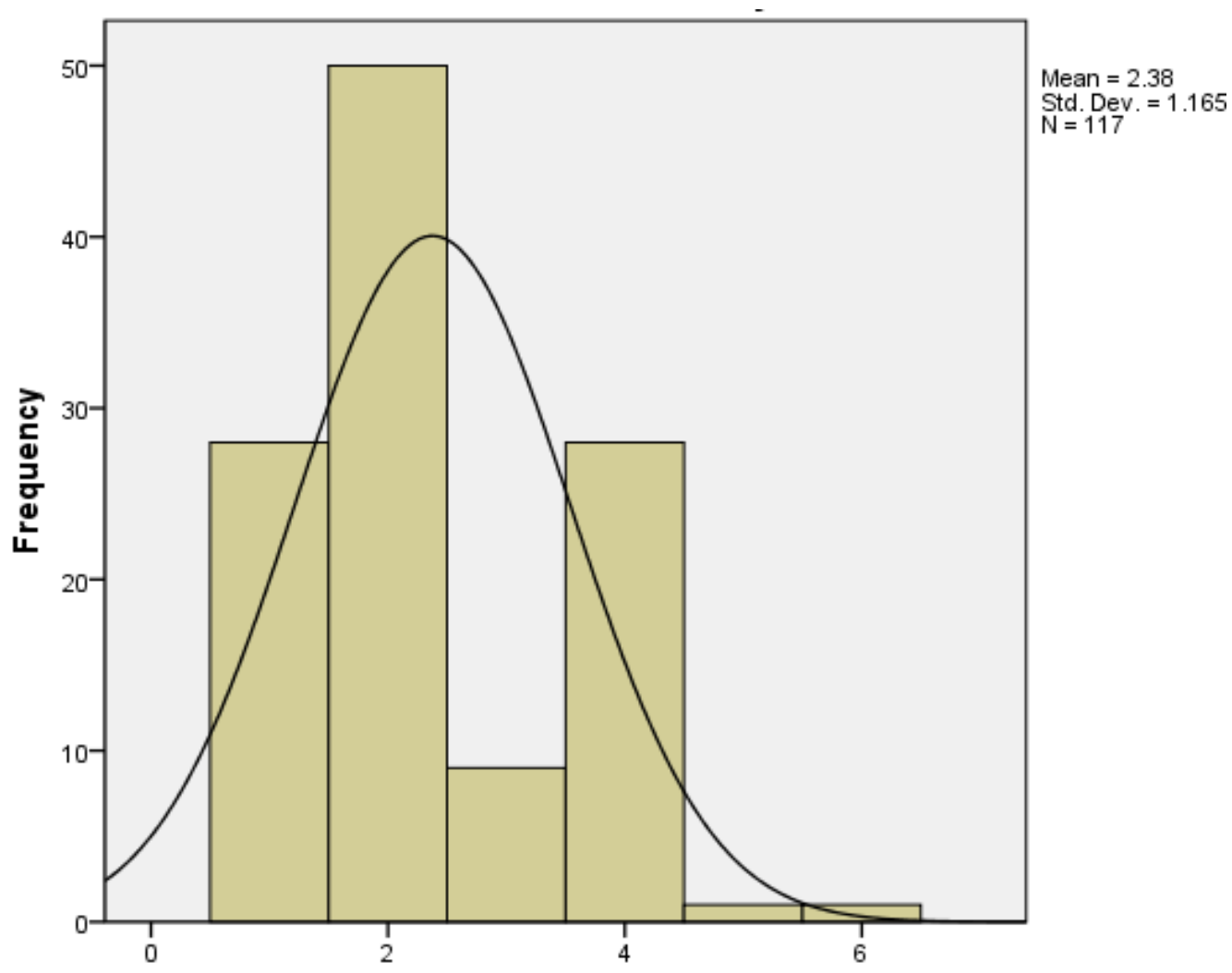

Figure 5. Race of sample.

national diploma and a bachelor degree, but not exceeding a postgraduate diploma, represented $88.9 \%$ of the sample, while 6 and $3.4 \%$ represented national diploma/bachelor degree and masters degree, respectively. There were only 2 doctoral degree holders in the sample, which represented $1.7 \%$ of the population (Figure 6).

A majority of the respondents indicated that they have been with their respective institutions for less than 5 years, whereas only $2.6 \%$ of the respondents disclosed that they had been with their institutions for over 21 years. Forty three members of the sample, which represented $36.8 \%$ indicated that they have worked for their respective organsations for between 6 to 10 years (Figure 7).

There is no significant relationship $(p>0.05)$ with regard to race and tenure on one hand and co-worker relations on the other.

Significant results in the Table 3 relate to employees perception of one another as helpful in times of need; an appreciation of the importance of knowledge sharing and the need to address disagreements promptly in order to carry on with the business of the establishment. There is a significant relationship between tenure $(r=.058 ; p<0.05)$ and the category direct supervisor. It is possible that as a health-related professional stays on the job, he enjoys much profound understanding of the business of the establishment through his supervisor (Table 4).

According to Table 5, there is a significant relationship between tenure and the category culture/work environment. The sense one gets here is that as the health-related professional aged in an organisation, he tends to understand the organisational culture of his organisation better, which makes him to have positive feelings about his organisation.

\section{Findings on demographic variables and their interaction with the core factors}

This part of the study presents interesting outcomes. There are varied levels of significant relationships between the new factors and the demographic variables.

\section{Gender}

There is no significant difference between males and females in all the new factors (Table 6). According to Table 6 , the $p$ value is greater than 0.05 . The Levene's test for equality of variances reveals that the variances are all equal, which means that we read the first line and not the second line. Therefore, for all the new factors there is no significant difference between males and 


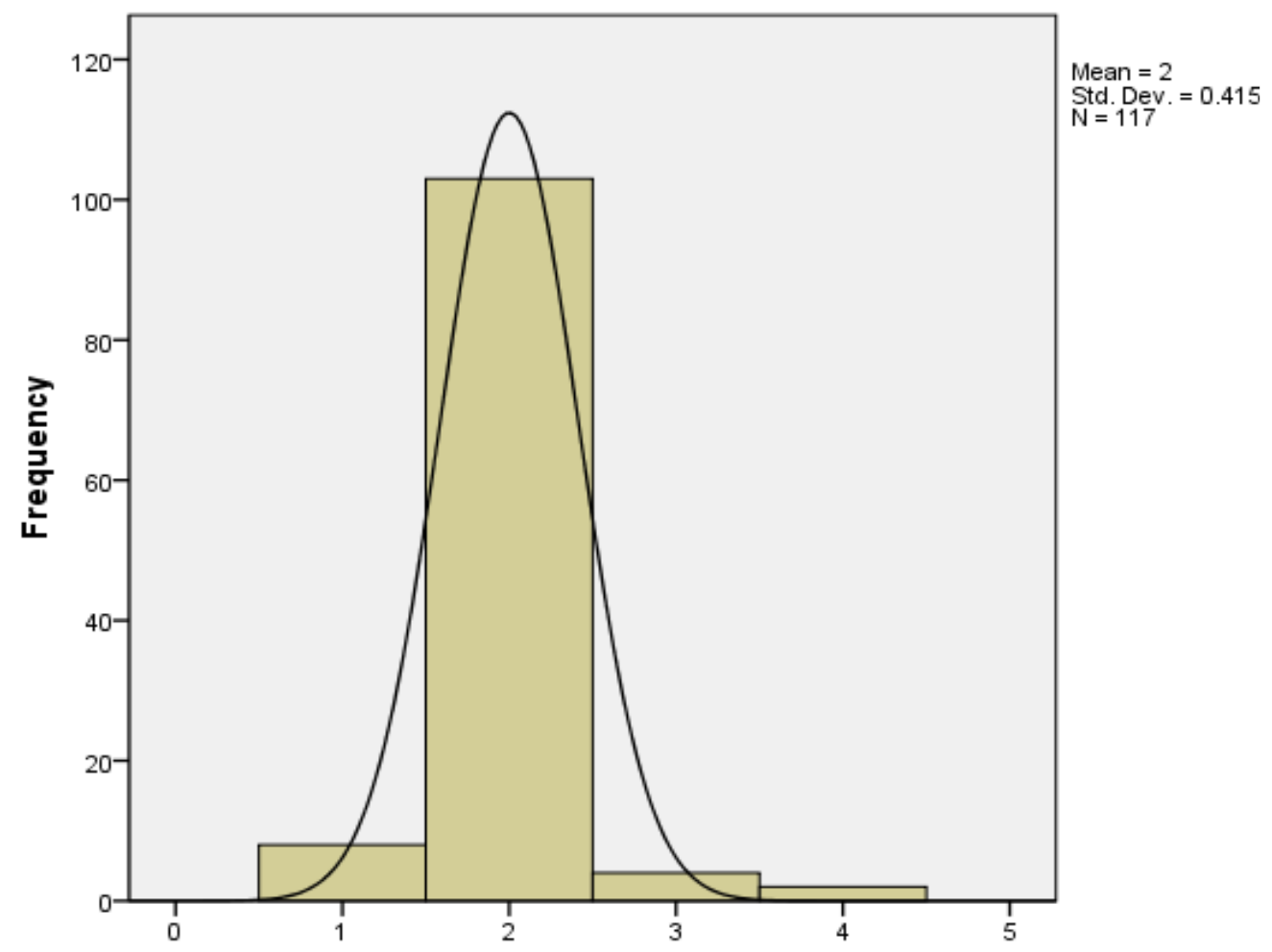

Figure 6. Level of education of sample.

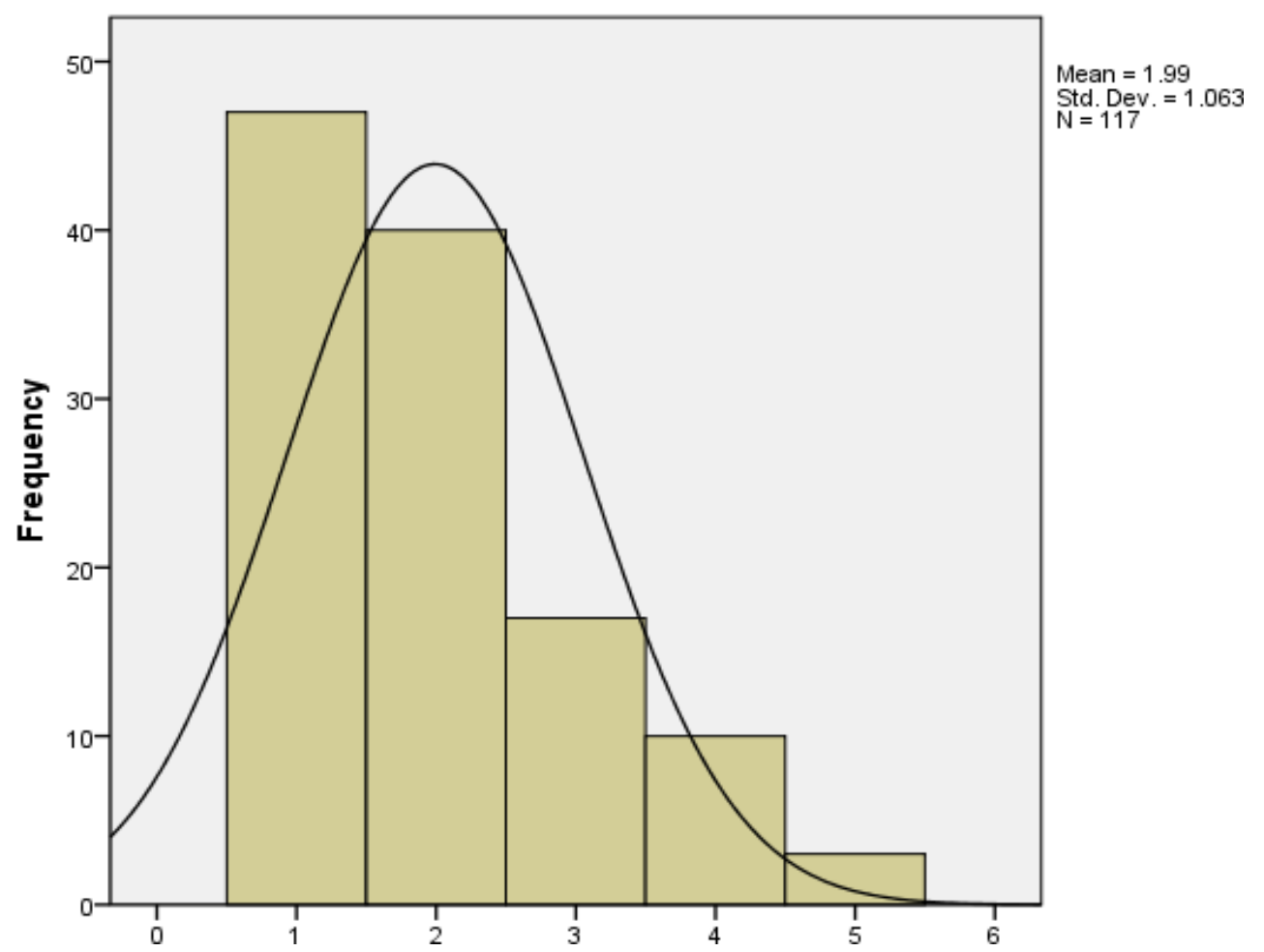

Figure 7. Tenure. 
Table 3. Correlating tenure and race (job satisfaction facets) and co-worker relations (data collection category).

\begin{tabular}{|c|c|c|c|c|c|c|c|c|}
\hline \multicolumn{9}{|c|}{ Correlations } \\
\hline Parameter & & $\begin{array}{l}\text { What race } \\
\text { are you? }\end{array}$ & $\begin{array}{l}\text { How long have } \\
\text { you been with this } \\
\text { organisation? }\end{array}$ & $\begin{array}{l}\text { I feel my } \\
\text { input is } \\
\text { valued by } \\
\text { my peers. }\end{array}$ & $\begin{array}{l}\text { Knowledge and } \\
\text { information sharing } \\
\text { are group norms } \\
\text { across the } \\
\text { organization. }\end{array}$ & $\begin{array}{l}\text { Employees } \\
\text { consult each } \\
\text { other when they } \\
\text { need support. }\end{array}$ & $\begin{array}{l}\text { Individuals } \\
\text { appreciate the } \\
\text { personal } \\
\text { contributions of } \\
\text { their peers. }\end{array}$ & $\begin{array}{l}\text { When disagreements } \\
\text { occur, they are } \\
\text { addressed promptly in } \\
\text { order to resolve them. }\end{array}$ \\
\hline \multirow{3}{*}{ What race are you? } & $\begin{array}{l}\text { Pearson } \\
\text { Correlation }\end{array}$ & 1 & 0.058 & -0.019 & -0.062 & 0.026 & 0.065 & 0.024 \\
\hline & Sig. (2-tailed) & & 0.532 & 0.840 & 0.505 & 0.781 & 0.485 & 0.801 \\
\hline & $\mathrm{N}$ & 117 & 117 & 117 & 117 & 117 & 117 & 117 \\
\hline \multirow{3}{*}{$\begin{array}{l}\text { How long have you } \\
\text { been with this } \\
\text { organisation? }\end{array}$} & $\begin{array}{l}\text { Pearson } \\
\text { Correlation }\end{array}$ & 0.058 & 1 & 0.120 & $0.207^{*}$ & $0.193^{*}$ & 0.090 & 0.086 \\
\hline & Sig. (2-tailed) & 0.532 & & 0.197 & 0.025 & 0.037 & 0.334 & 0.355 \\
\hline & $\mathrm{N}$ & 117 & 117 & 117 & 117 & 117 & 117 & 117 \\
\hline \multirow{2}{*}{$\begin{array}{l}\text { I feel my input is } \\
\text { valued by my peers. }\end{array}$} & $\begin{array}{l}\text { Pearson } \\
\text { Correlation }\end{array}$ & -0.019 & 0.120 & 1 & $0.533^{* *}$ & $0.584^{* *}$ & $0.639^{* *}$ & $0.677^{\star *}$ \\
\hline & Sig. (2-tailed) & 0.840 & 0.197 & & 0.000 & 0.000 & 0.000 & 0.000 \\
\hline \multirow{3}{*}{$\begin{array}{l}\text { Knowledge and } \\
\text { information sharing } \\
\text { are group norms } \\
\text { across the } \\
\text { organization. }\end{array}$} & $\begin{array}{l}\text { Pearson } \\
\text { Correlation }\end{array}$ & -0.062 & $0.207^{\star}$ & $0.533^{\star *}$ & 1 & $0.778^{\star *}$ & $0.713^{\star \star}$ & $0.585^{\star *}$ \\
\hline & Sig. (2-tailed) & 0.505 & 0.025 & 0.000 & & 0.000 & 0.000 & 0.000 \\
\hline & $\mathrm{N}$ & 117 & 117 & 117 & 117 & 117 & 117 & 117 \\
\hline \multirow{3}{*}{$\begin{array}{l}\text { Employees consult } \\
\text { each other when } \\
\text { they need support. }\end{array}$} & $\begin{array}{l}\text { Pearson } \\
\text { Correlation }\end{array}$ & 0.026 & $0.193^{*}$ & $0.584^{\star \star}$ & $0.778^{\star \star}$ & 1 & $0.887^{\star \star}$ & $0.605^{\star \star}$ \\
\hline & Sig. (2-tailed) & 0.781 & 0.037 & 0.000 & 0.000 & & 0.000 & 0.000 \\
\hline & $\mathrm{N}$ & 117 & 117 & 117 & 117 & 117 & 117 & 117 \\
\hline \multirow{3}{*}{$\begin{array}{l}\text { Individuals } \\
\text { appreciate the } \\
\text { personal } \\
\text { contributions of their } \\
\text { peers. }\end{array}$} & $\begin{array}{l}\text { Pearson } \\
\text { Correlation }\end{array}$ & 0.065 & 0.090 & $0.639^{\star \star}$ & $0.713^{\star \star}$ & $0.887^{\star \star}$ & 1 & $0.742^{\star \star}$ \\
\hline & Sig. (2-tailed) & 0.485 & 0.334 & 0.000 & 0.000 & 0.000 & & 0.000 \\
\hline & $\mathrm{N}$ & 117 & 117 & 117 & 117 & 117 & 117 & 117 \\
\hline $\begin{array}{l}\text { When } \\
\text { disagreements } \\
\text { occur, they are } \\
\text { addressed promptly } \\
\text { in order to resolve } \\
\text { them. }\end{array}$ & $\begin{array}{l}\text { Pearson } \\
\text { Correlation }\end{array}$ & 0.024 & 0.086 & $0.677^{\star *}$ & $0.585^{\star \star}$ & $0.605^{\star *}$ & $0.742^{\star *}$ & 1 \\
\hline
\end{tabular}

${ }^{*}$.Correlation is significant at the 0.05 level (2-tailed). ${ }^{* *}$. Correlation is significant at the 0.01 level (2-tailed). 
Table 4. Demographics and direct supervisor (data collection category).

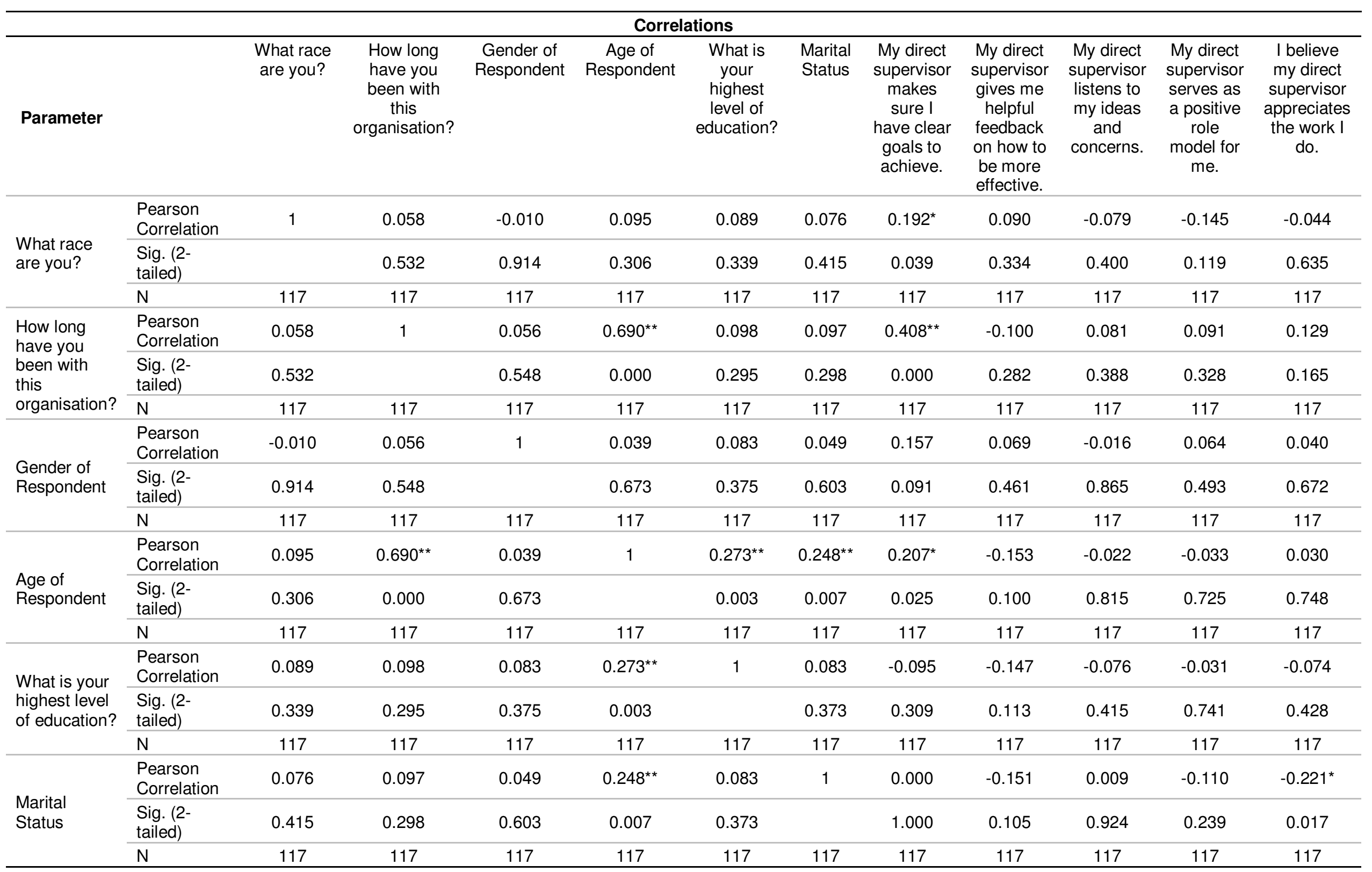


Table 4. Continued

\begin{tabular}{|c|c|c|c|c|c|c|c|c|c|c|c|c|}
\hline \multirow{3}{*}{$\begin{array}{l}\text { My direct } \\
\text { supervisor } \\
\text { makes sure } \\
\text { I have clear } \\
\text { goals to } \\
\text { achieve. }\end{array}$} & $\begin{array}{l}\text { Pearson } \\
\text { Correlation }\end{array}$ & $0.192^{*}$ & $0.408^{\star *}$ & 0.157 & $0.207^{\star}$ & -0.095 & 0.000 & 1 & 0.062 & 0.096 & 0.078 & -0.117 \\
\hline & $\begin{array}{l}\text { Sig. (2- } \\
\text { tailed) }\end{array}$ & 0.039 & 0.000 & 0.091 & 0.025 & 0.309 & 1.000 & & 0.506 & 0.303 & 0.403 & 0.209 \\
\hline & $\mathrm{N}$ & 117 & 117 & 117 & 117 & 117 & 117 & 117 & 117 & 117 & 117 & 117 \\
\hline \multirow{3}{*}{$\begin{array}{l}\text { My direct } \\
\text { supervisor } \\
\text { gives me } \\
\text { helpful } \\
\text { feedback } \\
\text { on how to } \\
\text { be more } \\
\text { effective. }\end{array}$} & $\begin{array}{l}\text { Pearson } \\
\text { Correlation }\end{array}$ & 0.090 & -0.100 & 0.069 & -0.153 & -0.147 & -0.151 & 0.062 & 1 & $0.468^{\star *}$ & $0.468^{\star *}$ & $0.377^{* *}$ \\
\hline & $\begin{array}{l}\text { Sig. (2- } \\
\text { tailed) }\end{array}$ & 0.334 & 0.282 & 0.461 & 0.100 & 0.113 & 0.105 & 0.506 & & 0.000 & 0.000 & 0.000 \\
\hline & $\mathrm{N}$ & 117 & 117 & 117 & 117 & 117 & 117 & 117 & 117 & 117 & 117 & 117 \\
\hline \multirow{3}{*}{$\begin{array}{l}\text { My direct } \\
\text { Supervisor } \\
\text { listens to } \\
\text { my ideas } \\
\text { and } \\
\text { concerns. }\end{array}$} & $\begin{array}{l}\text { Pearson } \\
\text { Correlation }\end{array}$ & -0.079 & 0.081 & -0.016 & -0.022 & -0.076 & 0.009 & 0.096 & $0.468^{\star *}$ & 1 & $0.688^{* *}$ & $0.253^{\star *}$ \\
\hline & $\begin{array}{l}\text { Sig. (2- } \\
\text { tailed) }\end{array}$ & 0.400 & 0.388 & 0.865 & 0.815 & 0.415 & 0.924 & 0.303 & 0.000 & & 0.000 & 0.006 \\
\hline & $\mathrm{N}$ & 117 & 117 & 117 & 117 & 117 & 117 & 117 & 117 & 117 & 117 & 117 \\
\hline \multirow{3}{*}{$\begin{array}{l}\text { My direct } \\
\text { supervisor } \\
\text { serves as } \\
\text { a positive } \\
\text { role model } \\
\text { for me. }\end{array}$} & $\begin{array}{l}\text { Pearson } \\
\text { Correlation }\end{array}$ & -0.145 & 0.091 & 0.064 & -0.033 & -0.031 & -0.110 & 0.078 & $0.468^{\star *}$ & $0.688^{* *}$ & 1 & $0.205^{\star}$ \\
\hline & $\begin{array}{l}\text { Sig. (2- } \\
\text { tailed) }\end{array}$ & 0.119 & 0.328 & 0.493 & 0.725 & 0.741 & 0.239 & 0.403 & 0.000 & 0.000 & & 0.026 \\
\hline & $\mathrm{N}$ & 117 & 117 & 117 & 117 & 117 & 117 & 117 & 117 & 117 & 117 & 117 \\
\hline \multirow{3}{*}{$\begin{array}{l}\text { I believe } \\
\text { my direct } \\
\text { supervisor } \\
\text { appreciates } \\
\text { the work } \\
\text { I do. }\end{array}$} & $\begin{array}{l}\text { Pearson } \\
\text { Correlation }\end{array}$ & -0.044 & 0.129 & 0.040 & 0.030 & -0.074 & $-0.221^{*}$ & 0.117 & $.377^{\star *}$ & $0.253^{* *}$ & $0.205^{\star}$ & 1 \\
\hline & $\begin{array}{l}\text { Sig. (2- } \\
\text { tailed) }\end{array}$ & 0.635 & 0.165 & 0.672 & 0.748 & 0.428 & 0.017 & 0.209 & 0.000 & 0.006 & 0.026 & \\
\hline & $\mathrm{N}$ & 117 & 117 & 117 & 117 & 117 & 117 & 117 & 117 & 117 & 117 & 117 \\
\hline
\end{tabular}

*. Correlation is significant at the 0.05 level (2-tailed). ${ }^{* *}$. Correlation is significant at the 0.01 level (2-tailed). 
Table 5. Demographics and culture/work environment (data collection category).

\begin{tabular}{|c|c|c|c|c|c|c|c|c|c|c|c|c|}
\hline \multicolumn{13}{|c|}{ Correlations } \\
\hline Parameter & & $\begin{array}{l}\text { What } \\
\text { race are } \\
\text { you? }\end{array}$ & $\begin{array}{c}\text { How long } \\
\text { have you } \\
\text { been with this } \\
\text { organisation? }\end{array}$ & $\begin{array}{c}\text { Gender of } \\
\text { Respondent }\end{array}$ & $\begin{array}{c}\text { Age of } \\
\text { Respondent }\end{array}$ & $\begin{array}{l}\text { What is your } \\
\text { highest level of } \\
\text { education? }\end{array}$ & $\begin{array}{l}\text { Marital } \\
\text { Status }\end{array}$ & $\begin{array}{l}\text { I feel } \\
\text { valued as } \\
\text { an } \\
\text { employee. }\end{array}$ & $\begin{array}{l}\text { I enjoy being } \\
\text { part of this } \\
\text { organization. }\end{array}$ & $\begin{array}{c}\text { Employees have } \\
\text { a good balance } \\
\text { between work } \\
\text { and personal } \\
\text { life. }\end{array}$ & $\begin{array}{c}\text { Morale is } \\
\text { high across } \\
\text { the } \\
\text { organization. }\end{array}$ & $\begin{array}{l}\text { Employees } \\
\text { speak highly } \\
\text { about this } \\
\text { organization. }\end{array}$ \\
\hline \multirow{3}{*}{$\begin{array}{l}\text { What race } \\
\text { are you? }\end{array}$} & $\begin{array}{l}\text { Pearson } \\
\text { Correlation }\end{array}$ & 1 & 0.058 & -0.010 & 0.095 & 0.089 & 0.076 & $0.254^{\star *}$ & -0.019 & 0.086 & 0.024 & 0.127 \\
\hline & $\begin{array}{l}\text { Sig. }(2- \\
\text { tailed) }\end{array}$ & & 0.532 & 0.914 & 0.306 & 0.339 & 0.415 & 0.006 & 0.840 & 0.355 & 0.801 & 0.173 \\
\hline & $\mathrm{N}$ & 117 & 117 & 117 & 117 & 117 & 117 & 117 & 117 & 117 & 117 & 117 \\
\hline \multirow{3}{*}{$\begin{array}{l}\text { How long } \\
\text { have you } \\
\text { been with this } \\
\text { organisation? }\end{array}$} & $\begin{array}{l}\text { Pearson } \\
\text { Correlation }\end{array}$ & 0.058 & 1 & 0.056 & $0.690^{* *}$ & 0.098 & 0.097 & $0.302^{* *}$ & 0.120 & 0.158 & 0.086 & $0.420^{* *}$ \\
\hline & $\begin{array}{l}\text { Sig. }(2- \\
\text { tailed) }\end{array}$ & 0.532 & & 0.548 & 0.000 & 0.295 & 0.298 & 0.001 & 0.197 & 0.088 & 0.355 & 0.000 \\
\hline & $\mathrm{N}$ & 117 & 117 & 117 & 117 & 117 & 117 & 117 & 117 & 117 & 117 & 117 \\
\hline \multirow{3}{*}{$\begin{array}{l}\text { Gender of } \\
\text { Respondent }\end{array}$} & $\begin{array}{l}\text { Pearson } \\
\text { Correlation }\end{array}$ & -0.010 & 0.056 & 1 & 0.039 & 0.083 & 0.049 & -0.013 & -0.108 & 0.062 & -0.096 & 0.106 \\
\hline & $\begin{array}{l}\text { Sig. }(2- \\
\text { tailed) }\end{array}$ & 0.914 & 0.548 & & 0.673 & 0.375 & 0.603 & 0.891 & 0.245 & 0.507 & 0.305 & 0.254 \\
\hline & $\mathrm{N}$ & 117 & 117 & 117 & 117 & 117 & 117 & 117 & 117 & 117 & 117 & 117 \\
\hline \multirow{3}{*}{$\begin{array}{l}\text { Age of } \\
\text { Respondent }\end{array}$} & $\begin{array}{l}\text { Pearson } \\
\text { Correlation }\end{array}$ & 0.095 & $0.690^{* *}$ & 0.039 & 1 & $0.273^{\star *}$ & $0.248^{* *}$ & 0.164 & 0.023 & 0.041 & -0.020 & $0.237^{*}$ \\
\hline & $\begin{array}{l}\text { Sig. }(2- \\
\text { tailed) }\end{array}$ & 0.306 & 0.000 & 0.673 & & 0.003 & 0.007 & 0.078 & 0.809 & 0.663 & 0.830 & 0.010 \\
\hline & $\mathrm{N}$ & 117 & 117 & 117 & 117 & 117 & 117 & 117 & 117 & 117 & 117 & 117 \\
\hline \multirow{3}{*}{$\begin{array}{l}\text { What is your } \\
\text { highest level } \\
\text { of education? }\end{array}$} & $\begin{array}{l}\text { Pearson } \\
\text { Correlation }\end{array}$ & 0.089 & 0.098 & 0.083 & $0.273^{\star *}$ & 1 & 0.083 & 0.000 & -0.086 & 0.000 & -0.086 & -0.095 \\
\hline & $\begin{array}{l}\text { Sig. }(2- \\
\text { tailed) }\end{array}$ & 0.339 & 0.295 & 0.375 & 0.003 & & 0.373 & 1.000 & 0.355 & 1.000 & 0.359 & 0.309 \\
\hline & $\mathrm{N}$ & 117 & 117 & 117 & 117 & 117 & 117 & 117 & 117 & 117 & 117 & 117 \\
\hline \multirow{3}{*}{ Marital Status } & $\begin{array}{l}\text { Pearson } \\
\text { Correlation }\end{array}$ & 0.076 & 0.097 & 0.049 & $0.248^{\star *}$ & 0.083 & 1 & 0.016 & -0.141 & 0.074 & $-0.197^{\star}$ & -0.025 \\
\hline & $\begin{array}{l}\text { Sig. (2- } \\
\text { tailed) }\end{array}$ & 0.415 & 0.298 & 0.603 & 0.007 & 0.373 & & 0.865 & 0.130 & 0.428 & 0.034 & 0.789 \\
\hline & $\mathrm{N}$ & 117 & 117 & 117 & 117 & 117 & 117 & 117 & 117 & 117 & 117 & 117 \\
\hline \multirow{3}{*}{$\begin{array}{l}\text { I feel valued } \\
\text { as an } \\
\text { employee. }\end{array}$} & $\begin{array}{l}\text { Pearson } \\
\text { Correlation }\end{array}$ & $0.254^{\star *}$ & $0.302^{\star *}$ & -0.013 & 0.164 & 0.000 & 0.016 & 1 & $0.580^{\star *}$ & $0.241^{* *}$ & $0.443^{* *}$ & $0.210^{*}$ \\
\hline & $\begin{array}{l}\text { Sig. (2- } \\
\text { tailed) }\end{array}$ & 0.006 & 0.001 & 0.891 & 0.078 & 1.000 & 0.865 & & 0.000 & 0.009 & 0.000 & 0.023 \\
\hline & $\mathrm{N}$ & 117 & 117 & 117 & 117 & 117 & 117 & 117 & 117 & 117 & 117 & 117 \\
\hline
\end{tabular}


Table 5. Continued.

\begin{tabular}{|c|c|c|c|c|c|c|c|c|c|c|c|c|}
\hline \multirow{2}{*}{$\begin{array}{l}\text { I enjoy being } \\
\text { part of this } \\
\text { organization. }\end{array}$} & $\begin{array}{l}\text { Pearson } \\
\text { Correlation }\end{array}$ & -0.019 & 0.120 & -0.108 & 0.023 & -0.086 & -0.141 & $0.580^{\star \star}$ & 1 & $0.231^{*}$ & $0.677^{\star \star}$ & $0.193^{*}$ \\
\hline & $\begin{array}{l}\text { Sig. (2- } \\
\text { tailed) }\end{array}$ & 0.840 & 0.197 & 0.245 & 0.809 & 0.355 & 0.130 & 0.000 & & 0.012 & 0.000 & 0.037 \\
\hline \multirow{3}{*}{$\begin{array}{l}\text { Employees } \\
\text { have a good } \\
\text { balance } \\
\text { between } \\
\text { work } \\
\text { and } \\
\text { personal } \\
\text { life. }\end{array}$} & $\begin{array}{l}\text { Pearson } \\
\text { Correlation }\end{array}$ & 0.086 & 0.158 & 0.062 & 0.041 & 0.000 & 0.074 & $0.241^{* *}$ & $0.231^{*}$ & 1 & $0.334^{* *}$ & 0.118 \\
\hline & $\begin{array}{l}\text { Sig. }(2- \\
\text { tailed) }\end{array}$ & 0.355 & 0.088 & 0.507 & 0.663 & 1.000 & 0.428 & 0.009 & 0.012 & & 0.000 & 0.206 \\
\hline & $\mathrm{N}$ & 117 & 117 & 117 & 117 & 117 & 117 & 117 & 117 & 117 & 117 & 117 \\
\hline \multirow{2}{*}{$\begin{array}{l}\text { Morale is } \\
\text { high across } \\
\text { the } \\
\text { organization. }\end{array}$} & $\begin{array}{l}\text { Pearson } \\
\text { Correlation }\end{array}$ & 0.024 & 0.086 & -0.096 & -0.020 & -0.086 & $-0.197^{\star}$ & $0.443^{* *}$ & $0.677^{* *}$ & $0.334^{* *}$ & 1 & 0.181 \\
\hline & $\begin{array}{l}\text { Sig. }(2- \\
\text { tailed) }\end{array}$ & 0.801 & 0.355 & 0.305 & 0.830 & 0.359 & 0.034 & 0.000 & 0.000 & 0.000 & & 0.051 \\
\hline \multirow{3}{*}{$\begin{array}{l}\text { Employees } \\
\text { speak } \\
\text { highly } \\
\text { about this } \\
\text { organization. }\end{array}$} & $\begin{array}{l}\text { Pearson } \\
\text { Correlation }\end{array}$ & 0.127 & $0.420^{\star *}$ & 0.106 & $0.237^{*}$ & -0.095 & -0.025 & $0.210^{*}$ & $0.193^{\star}$ & 0.118 & 0.181 & 1 \\
\hline & $\begin{array}{l}\text { Sig. }(2- \\
\text { tailed) }\end{array}$ & 0.173 & 0.000 & 0.254 & 0.010 & 0.309 & 0.789 & 0.023 & 0.037 & 0.206 & 0.051 & \\
\hline & $\mathrm{N}$ & 117 & 117 & 117 & 117 & 117 & 117 & 117 & 117 & 117 & 117 & 117 \\
\hline
\end{tabular}

**. Correlation is significant at the 0.01 level (2-tailed). *. Correlation is significant at the 0.05 level (2-tailed).

females. This finding thus suggests that gender has no relationship to the new factors.

\section{Income}

Five income groups were delineated for this study. These included (1) less than R100 000; (2) R101 000 to R200 000; (3) R201 000 to R300 000; (4) R301 000 up to R400 000; and (5) R401 000 to R500 000. A frequency analysis was then conducted to determine the number of respondents in each income group. The result showed that only two respondents belonged to the R100 000 to R200 000 income groups, respectively, while $77 \% \quad(n=90)$ of the sample belonged to the R201 000 to R300 000 income group. The rest were within the R301 000 to R400 $000(n=23)$ and R401 000 up to R500 $000(n=2)$.

Given the distribution, it was considered necessary for the purposes of much clearer statistical computation to merge the first two (less than R100 000 and R101 $000-200000$ ) with the third income group (R201 $000-300000)$. The last groups (R301 000 - R400 000 and R401 000
- R5000 000) were also merged. This merger resulted in two distinct groups: Group 1 representing those who earn up to R300 000, while group 2 represents those who earn from R301 000 and above. This new distribution is shown below in Table 5.

Once a new income group was delineated, the researchers went further to find out if there was a significant difference between the two income groups with reference to the new factors. And because there are only two groups, a T-test analysis was employed (Table 7). 
Table 6. Groups statistics for gender.

\begin{tabular}{|c|c|c|c|c|c|}
\hline \multicolumn{6}{|c|}{ Group statistics } \\
\hline New factors & $\begin{array}{l}\text { Gender of } \\
\text { respondent }\end{array}$ & $\mathbf{N}$ & Mean & $\begin{array}{l}\text { Standard } \\
\text { deviation }\end{array}$ & $\begin{array}{c}\text { Standard error } \\
\text { mean }\end{array}$ \\
\hline \multirow{2}{*}{ Role clarification and job design } & Male & 62 & 3.96 & 0.481 & 0.061 \\
\hline & Female & 55 & 4.12 & 0.495 & 0.067 \\
\hline \multirow{2}{*}{ Integrated leadership and knowledge sharing } & Male & 62 & 3.60 & 0.920 & 0.117 \\
\hline & Female & 55 & 3.51 & 1.010 & 0.136 \\
\hline \multirow{2}{*}{ Self-efficacy } & Male & 62 & 3.87 & 0.504 & 0.064 \\
\hline & Female & 55 & 3.85 & 0.670 & 0.090 \\
\hline \multirow{2}{*}{ Family-friendly work environment } & Male & 62 & 2.91 & 0.585 & 0.074 \\
\hline & Female & 55 & 2.90 & 0.569 & 0.077 \\
\hline \multirow{2}{*}{ Leader credibility and innovation } & Male & 62 & 3.98 & 0.643 & 0.082 \\
\hline & Female & 55 & 4.04 & 0.597 & 0.080 \\
\hline \multirow{2}{*}{ Excellent customer relations and effective technology } & Male & 62 & 4.416 & 0.5151 & 0.0654 \\
\hline & Female & 55 & 4.520 & 0.4365 & 0.0589 \\
\hline \multirow{2}{*}{ Equitable performance management } & Male & 62 & 3.87 & 0.323 & 0.041 \\
\hline & Female & 55 & 3.96 & 0.317 & 0.043 \\
\hline
\end{tabular}

Table 7. New income group distribution.

\begin{tabular}{lccccc}
\hline \multicolumn{5}{c}{ New income group distribution } \\
\hline \multirow{2}{*}{ Valid } & 1 & Frequency & Percent & Valid percent & Cumulative percent \\
& 2 & 92 & 78.6 & 78.6 & 78.6 \\
& Total & 117 & 21.4 & 21.4 & 100.0 \\
\hline
\end{tabular}

Table 8 indicates that there is no significant difference in the average mean scores for role clarification and job design, integrated leadership and knowledge sharing, leader credibility and innovation and excellent customer relations and effective technology.

\section{Self-efficacy}

There is a significant difference in the average for the factor - self-efficacy - between the two income groups $(p<0.05)$. The means for self-efficacy is 3.79 and 4.14 . The earlier points closer to neutral and agree but 4.14 lies within the agree and strongly agree axis. This means that the population that has $\mathrm{R} 100,000-300,000$ income is closer to neutral, unlike those who earn from R301,000 upwards who are within the range of agree and strongly agree. This suggests that those who earn from R301, 000 upwards feel a stronger sense of self-efficacy than all other groups.

\section{Family-friendly work environments}

There is a significant difference in the mean for familyfriendly work environments $(p<0.01)$. The mean scores indicate a closer proximity to neutral.

\section{Equitable performance management}

There is a significant difference in the means $(p<0.001$. mean score: $3.86 / 4.11$ ), which suggests a strong slant 
Table 8. T-test for the two income groups against the new factors.

\begin{tabular}{lccccc}
\hline & Group statistics & & & & \\
\hline Parameter & New Inc & N & Mean & $\begin{array}{c}\text { Standard } \\
\text { deviation }\end{array}$ & $\begin{array}{c}\text { Standard error } \\
\text { mean }\end{array}$ \\
\hline Role clarification and job design & 1 & 92 & 3.98 & 0.460 & 0.048 \\
& 2 & 25 & 4.22 & 0.566 & 0.113 \\
Integrated leadership and knowledge sharing & 1 & 92 & 3.49 & 0.958 & 0.100 \\
& 2 & 25 & 3.83 & 0.939 & 0.188 \\
Self-efficacy & 1 & 92 & 3.79 & 0.605 & 0.063 \\
& 2 & 25 & 4.14 & 0.402 & 0.080 \\
Family-friendly work environment & 1 & 92 & 2.82 & 0.551 & 0.057 \\
Leader credibility and innovation & 2 & 25 & 3.21 & 0.570 & 0.114 \\
Excellent customer relations and effective technology & 1 & 92 & 4.02 & 0.617 & 0.064 \\
& 2 & 25 & 3.95 & 0.639 & 0.128 \\
Equitable performance management & 1 & 92 & 4.446 & 0.5238 & 0.0546 \\
\hline
\end{tabular}

towards agree and disagree.

\section{Tenure}

There were four tenure groups, namely less than 5 years; 6 to 10 years; 11 to 15 years; and 16 years and above. A one-way analysis of variances was deployed to examine the degree of relationships between the groups and the new factors.

\section{Role clarification and job design}

A significant difference exists in the mean between the different tenure groups $(p<0.01)$, but they are mostly on the agree side.

\section{Self-efficacy}

A significant difference exists $(p<0.05)$. Family-friendly work environment: A significant difference exists $(p<0.05)$. The mean for 16 years or more is on the agree side.

\section{Leader credibility and innovation}

There is a significant difference in the average mean scores $(p<0.05)$. Interestingly, all the mean scores are on the agree side.

\section{Equitable performance management}

There is a significant difference $(p<0.001)$ with the mean scores weighing heavily on the agree side.

\section{Multiple comparisons: Tenure}

On the basis of the significant difference between the mean scores of the various factors, it was important to establish where the significant differences exist among the different tenure groups. As a result, a multiple comparison of all the tenure groups was undertaken for each of the new factors.

\section{Role clarification and job design}

There is a significant difference $(p<0.05)$ between those who have 6 to 10 years experience and 16 years and above when compared to those who have worked for less than 5 years. Those who have 6 to 10 years work experience interact more with those who have 16 years and above in terms of significant difference in means $(p<0.001)$. Essentially those who have worked for 16 years or more show a stronger relationship in the way that they relate to the factor role clarification and job design, especially given that their means are strongly 
close to the strongly agree side.

\section{Self-efficacy}

There is a significant difference between the tenure group of less than 5 years and 16 years or more $(p<0.05)$.

\section{Family-friendly work environment}

There is a significant difference between the tenure groups 6 to 10 years and 16 years or more $(p<0.05)$. There is also a significant difference between the groups 11 to 15 years and 16 years or more $(p<0.05)$.

\section{Leader credibility and innovation}

Only a tenure group emerged here. There is a significant difference between the less than 5 years group and 11 to 15 years group $(p<0.05)$.

\section{Equitable performance management}

There is a significant difference for those who have worked for 16 years or more $(p<0.05)$. From the Post Hoc Tests (Pairwise Comparisons), it was clear that those who have 16 years or more of work experience in healthrelated professions are much stronger (within the range of strongly agree) in their relationship to tenure category.

\section{Race}

Four major race groups were delineated for this study, which included African Blacks, Whites, Coloureds and the Indian/Asian/other groups.

\section{Role clarification and job design}

A significant difference exists among the different races in terms of the mean scores. They are all on the agree side, but it is revealing that Whites are much closer to the strongly agree side.

\section{Self-efficacy}

There is a significant difference in terms of the mean scores for the factor self-efficacy. Africans are closer to neutral, but on the agree side, while Whites are on the strongly agree side. Indians and the Coloureds are also on the agree side.

\section{Family-friendly work environment}

Although there is no significant difference in the mean scores for all the race groups, the Whites are actually on the neutral side (3.07). Other race groups are on the disagree side. Previous studies support this finding. Jacobs (2005: 235) disclosed the yearnings of health workers with regards to family friendly work practices.

\section{Leader credibility and innovation}

There is a significant difference in the mean scores for this category. However it must be noted that all the race groups are on the agree side. The Indian and Asian categories are much closer to strongly agree.

\section{Excellent customer relations and effective technology}

There is a significant difference between the mean scores $(p<0.05)$. All the race groups are on the agree side.

\section{Equitable performance management}

There is a significant difference between the mean scores $(p<0.05)$.

\section{Multiple comparisons: Race}

\section{Role clarification and job design}

In this category, a significant difference exists between Whites and Africans ( $p>0.001)$.

\section{Self-efficacy}

Within the factor Self-efficacy, a significant difference exists between Africans and all the other race groups $(p>0.001)$.

\section{Leader credibility and innovation}

In this factor, there is a significant relationship between Indians/Asians and Whites ( $p>0.001)$, as well as Africans and Whites, and Africans and Indians/Asians ( $p>0.001)$.

\section{Excellent customer relations and effective technology}

In this factor a significant relationship exists between 
Africans and Whites ( $p>0.001)$.

\section{Equitable performance management}

In this factor, a significant relationship exists between Africans and Whites $(p<0.05)$.

\section{Marital status}

Only three marital status groups were utilized for this study, which included single, married and separated. There was a significant relationship between the different marital status groups $(p<0.05)$ within the factor leader credibility and innovation. However, to understand where the difference lies among different marital status groups, the researchers conducted a Post Hoc test. Thus, through multiple comparisons of all the groups, it was found that the difference existed between married and separated employees.

\section{Age}

Four different age groups were selected for this study. These included 21 to 30 years; 31 to 40 years; 41 to 50 years; and the 51 to 60 years age groups.

\section{One way analysis of variance (ANOVA) for the different age groups}

\section{Role clarification and job design}

There is a significant difference between the age groups 31 to 40 years and 51 to 60 years $(p<0.05)$. This finding perhaps supports previous studies, which found that as one grew older, one tended to understand one's work roles better. The risk with this is that not all employees would stay long in an organisation. It has been empirically confirmed that employees are more likely to leave the employment of an organisation because of poor role clarity and job design. Therefore, it should be a critical element of an organisation's mission to ensure that members of an organisation are clear on what they are supposed to do on a regular basis. Organisations should not assume that their members' roles become clearer with time; they must find ways to clarify goals and design jobs in such a manner that employees are excited about their jobs.

\section{Equitable performance management}

The age groups 31 to 40 years share a significant difference with the age group 51 to 60 years $(p<0.05)$.
This is an indication that health-related personnel who are 31 years and above favour equitable performance management. Writing about the differences in generations of workers (Generation $Y$ and the rest), James et al. (2007: 3) argue that older workers tended to be more loyal than younger workers on the basis of improved structure and life purpose that work provides (maintaining and providing for dependents, fair treatment at work, and taking care of costly health insurance). They also believed that older workers were interested in being promoted, eager for training and can serve as mentors to younger workers.

\section{Exploratory factor analysis of identified employee satisfaction variables}

Exploratory factor analysis is performed in order to understand how many factors exist among a set of variables (Zikmund et al., 2010: 593). The researchers took initial step to explore all the items in the categories and then determined their degree of connectedness or otherwise. Following this, a rotated component matrix was realised. The rotated component matrix was also important because it helped to identify the most interpretable and meaningful structure of the groups of variables (Leong and Austin, 2006: 251). From the rotated component matrix, it was then necessary to group together all the items with a high correlation to each other. This approach amplifies Kline's (1994: 7) statement: 'In exploratory analysis, the aim is to explore the field, to deliver the main constructs or dimensions ... [essentially to ask] what constructs or dimensions account for correlations [in a study]. This was an exact element of the present study. Each grouped item is considered as a factor and then labelled differently. The new factors are role clarification and job design; equitable performance management; and integrated leadership and knowledge sharing. The others include self-efficacy; family-friendly work environments (FFWE's), leader credibility and innovation and excellent customer relations and technology. The grouped factors and their reliability coefficient $\alpha$ are presented in Figure 8.

\section{DISCUSSION OF THE KEY FACTORS OF EMPLOYEE SATISFACTION}

Robbins et al. (2009: 221) describe role clarity as the understanding of a set of expected behaviour patterns by someone occupying a given position. According to Rowe et al. (2005: 1026, 1032), improving role clarity is an urgent need in health care establishments, especially in low and middle income countries. Albion et al. (2008: 279) found that role clarity was the only organisational climate variable that emerged in their study as a unique contributor to the formation of intentions to leave the 


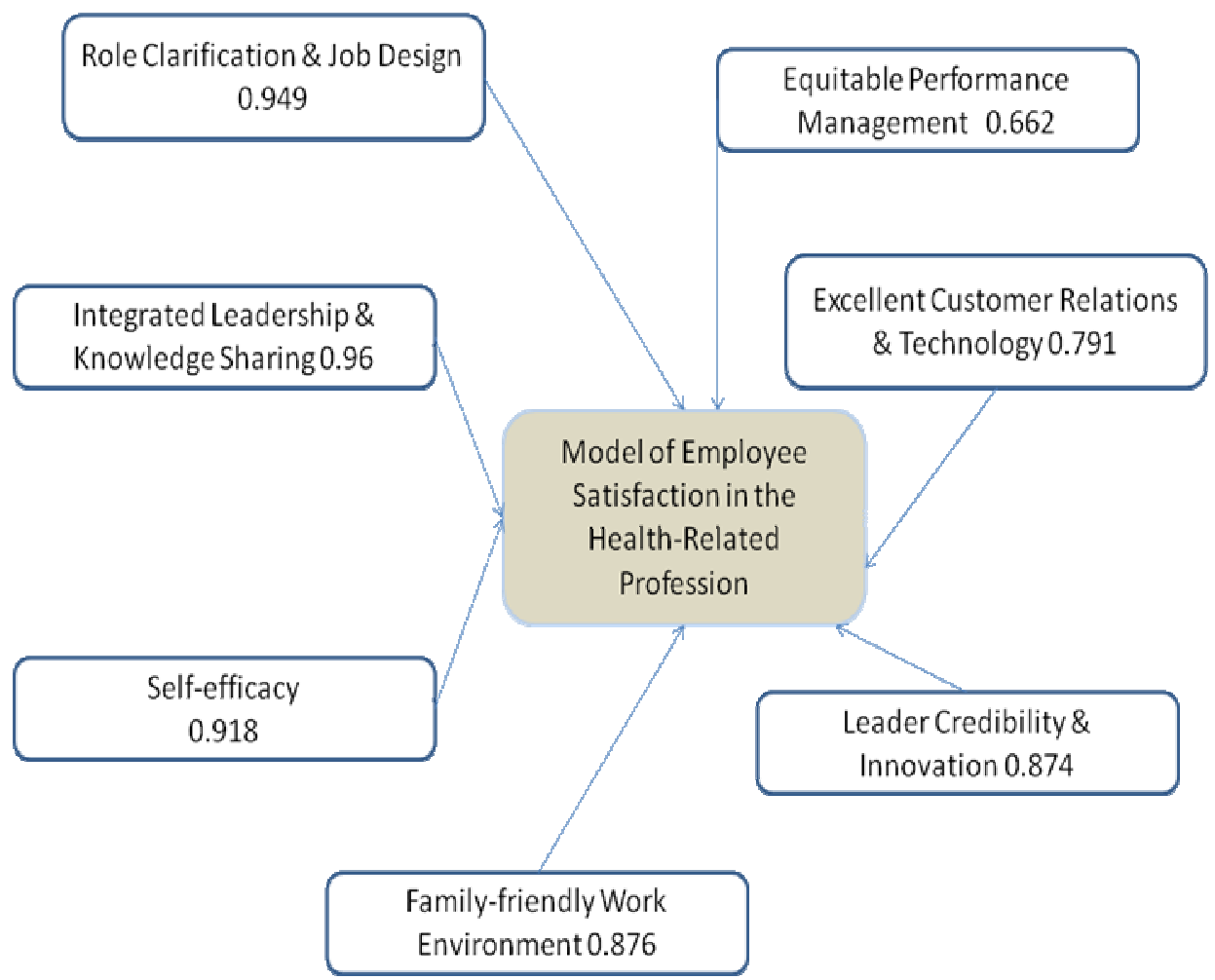

Figure 8. Key factors of employee satisfaction.

health profession. Nel et al. (2008: 394) state that job design provides job satisfaction for the job holder and aids to achieve the strategic goals of an organisation.

To retain health-related professionals will require unlimited career development opportunities based on, among other factors, equitable performance management. A healthy work environment provides a grounded structure with policies, procedures, and systems that allow employees to achieve personal and organisational goals versus an unhealthy work environment, which is fraught with stress, hostility and authoritarianism (Disch, 2000, cited in Strydom and Roodt, 2006: 15). Being informed about important issues within the organisation is an important function in any organisation (van der Ploeg and Kleber, 2003).

Integrated leadership can simply be defined as an opportunity presented to all members of an organisation to participate in making decisions that affect them. This can be referred to as empowering leadership, which Srivastava et al. (2006: 1240) define as behaviours whereby power is shared with subordinates, which raises their levels of intrinsic motivation. Lin (2008) suggests regular informal departmental interactions such as workshops or social activities and insisted these were equally effective in increasing communication opportunities and enhancing the sense of internal identification with the organisation. Lin states that these activities would enhance trust and commitment among units because knowledge sharing is the fundamental means through which employees can contribute to knowledge application, innovation, and ultimately the competitive advantage of an organisation (Jackson et al., 2006).

Low self-efficacy could be related to high levels of burnout. This was the finding of Rothman (2003: 22) in a study that dealt with burnout and engagement. Jobs that enhance situational and personal control also have the potential to lead to higher self-management efficacy beliefs (Strydom and Roodt, 2006: 17). Psychological meaningfulness results in a much improved output (Xu and Thomas, 2011: 401).

Health-related professionals work in highly pressured environments, and are often detached from their families and other social environments. There is, therefore, a high need for various support mechanisms for these professionals. These support mechanisms can include flexible work schedules, dependent care assistance, leave arrangements, counselling and referral services, which Ngo et al. (2009: 667) refer to as components of family-friendly work environments. Davis and Kalleberg (2006) claimed that FFWE's were introduced to help employees achieve a good balance between their work and family. Today's health care environment demands leaders who inspire others with the vision of what can be accomplished (Medley and Larochelle, 1995).

Inspiration can also come from positive feedback and 
functional systems. Providing sufficient performance feedback to employees helps to boost positive attitudes towards the organisation and helps to prevent early intentions to leave the organisation (Coetzee and Schreuder, 2010: 262).

Every organisation has a different calibre of partners such as customers and suppliers. Customers are usually the reason for any organisation's existence and hence organisations must have strategic relationships with them. As partners, they should maintain good relations with each other, gain experience with each other, develop a common language and perspective, which will reduce misunderstanding and enhance collaboration (Larson and Gray, 2011: 431), thereby improving the return on investment. Given the nature of the work of health-related professions, one can safely say that excellent customer relations are achievable through functional technology.

\section{CONCLUSION AND RECOMMENDATIONS}

Empirical literature has provided enormous evidence to show that when employees are satisfied, organisations experience high productivity, low absenteeism and turnover, less job stress and burnout, better safety performance, and a stronger tendency to achieve customer loyalty among others. The reverse is the case when employees are dissatisfied. Employers will incur massive costs when employees stay away from work as a result of illness or any other untoward reason. Dissatisfied employees are usually the ones who stay away from work. They do so because they experience physical, psychological and social unhappiness.

Several calls have been made in South Africa by researchers to health establishments with regards to the management of their personnel. These calls have been made on the basis of the high levels of dissatisfaction that have been reported by health establishment workers. Health establishments cannot fold their hands, while their personnel continuously seek greener pastures either in other sectors or overseas. South African health establishments are supposed to cater for the well being of the South African population. There is therefore a need to begin to pay much closer attention to the health-related professionals who provide functions of assessment, diagnosis, emergency care, and treatment from primary prevention through to specialist disease management and rehabilitation across a wide range of locations within acute, primary and community care.

This study will no doubt add value to, as well as expand the understanding of, employee satisfaction within the health-related profession. In addition, the study has produced a model which health-related professions can utilise to manage themselves better. It is hoped that the model would serve the health-related profession with better gains, such as reduction in health-related professional attrition, low levels of trust between management and staff and the high incidence of absenteeism. These constituted the research problems.

For future studies, the researchers suggest (1) an enlargement of the sample size to give effect to a possible generalisation of findings; (2) the study can be extended to other provinces of South Africa; (3) perhaps a comparative examination of the private and public sector health-related professional; and (4) perhaps a comparative examination of health-related professionals in independent practice.

\section{REFERENCES}

Albion MJ, Fogarty GJ, Machin MA, Patrick J (2008). Predicting absenteeism and turnover intentions in the health professions. Aust. Health Rev. 32(2):271-281.

Buchanan DA, Bryman A (Eds.) (2009). The SAGE Handbook of Organisational Research Methods. London: SAGE.

Bundred PE, Levitt C (2000). Medical migration: who are the real losers? Lancet 356:245-246.

Chen S, Yang C, Shiau J, Wang H (2006). The development of an employee satisfaction model for higher education. The TQM Mag. 18(5):484-500

Coetzee M, Schreuder D (Eds.) (2010). Personnel Psychology. An Applied Perspective. Cape Town: Oxford.

Cronje SE (2010). A strategic management model for the provision of housing by the City of Cape Town. Unpublished Doctor of Technology degree thesis. Cape Peninsula University of Technology.

Dane FC (2011). Evaluating Research. London: Sage Publications.

De Cock C (2006). A Creativity Model for the Analysis of Continuous Improvement Programmes: A Suggestion to Make Continuous Improvement Continuous. Creat. Innov. Manag. 2(3):156-165.

De Villiers MR, De Villiers PJT (2004). Doctors' views of working conditions in rural hospitals in the Western Cape. South Afr. Family Pract. 46(3):21-26.

De Witte $\mathrm{H}$ (2005). Job insecurity; review of international literature on definitions, prevalence, antecedents and consequences. SA J. Ind. Psychol. 31(4):1-6.

Gilson L, Palmer N, Schneider H (2005). Trust and health worker performance: Exploring a conceptual framework using South African evidence. Soc. Sci. Med. 61:1418-1429.

Govender V (2006). Job satisfaction among healthcare professionals in Area Military Health unit, KwaZulu Natal. Unpublished M.BA thesis. University of KwaZulu Natal.

Grobler PA, Warnich S, Carrell MR, Elbert NF, Hatfield RD (2006). Human Resource Management in South Africa. (3rd ed.). London: Thomson Learning.

Hopkins WG (2007). Quantitative research design. Available at http://www.sportsci.org/jour/0001/wghdesign.html. [Retrieved 26 August, 2011].

Jackson SE, Chuang CH, Harden EE, Jiang Y, Joseph JM (2006). Toward developing human resource management systems for knowledge-intensive teamwork. In J. M. Joseph (Ed.), Res. Pers. Hum. Resour. Manag. 25:27-70. Amsterdam: JAI.

Judge TA, Locke EA (1993). Effect of dysfunctional thought processes on subjective well-being and job satisfaction. J. Appl. Psychol. 78(3):475-490.

Kitto SC, Chesters J, Grbich C (2008). Quality in qualitative research. Criteria for authors and assessors in the submission and assessment of qualitative research articles for the Medical Journal of Australia. Med. J. Aust. 188:243-246.

Kline P (1994). An easy guide to factor analysis. London: Routledge.

Larson EW, Gray CF (2011). Project management. The managerial process. ( $5^{\text {th }}$ ed.) Singapore: McGraw-Hill.

Leong FTL, Austin JT (Eds.) (2006). The Psychology Research Handbook. A Guide for Graduate Students and Research Assistants $\left(2^{\text {nd }}\right.$ ed.). London: SAGE.

Lin W (2008). The Effect of Knowledge Sharing Model. Expert Syst. Appl. 34:1508-1521. 
Luddy N (2005). Job satisfaction amongst employees at a public health institution in the Western Cape. Unpublished Master of Commerce degree thesis. University of the Western Cape.

Makie VV (2006). Stress and coping strategies amongst registered nurses working in a South African tertiary hospital. Unpublished Master of Commerce degree thesis. University of the Western Cape.

Makwetla T (2004). Keynote address by Premier Thabang Makwetla at the Mpumalanga Provincial Government and Public Sector Unions Service Delivery Summit. Loskop Dam, Aventura. Thursday 22 July, 2004.

Malterud K (2001). Qualitative research: standards, challenges, and guidelines. Lancet 358:483-488.

Marchal B, Kegels G (2003). Health workforce imbalances in times of globalization: brain drain or professional mobility? Int. J. Health Plan. Manag. 18:89-101.

Mariani D, Gcaba R, Dalton J (2003). Survey on knowledge, attitude and practice (KAP) on professional nurses working at primary health care level. Retrieved from http://www.kznhealth.gov.za/italian/kapsyrvey.pdf. February 20, 2005

McCann L, Hughes CM, Adair CG, Cardwell C (2009). Assessing job satisfaction and stress among pharmacists in Northern Ireland. Pharm. World Sci. 31:188-194.

Medley F, Larochelle DR (1995). Transformational Leadership and Job Satisfaction. Nurs. Manag. 26(9):64JJ-64NN.

Mokoka E, Oosthuizen MJ, Ehlers VJ (2010). Retaining professional nurses in South Africa: Nurse managers' perspectives. Health SA Gesondheid 15(1):484,9.

Mrara MT (2010). An investigation of turnover and retention factors of health professional staff within the Eastern Cape Department of Health. Unpublished Masters degree thesis. Rhodes University.

Nel PS, Werner A, Haasbroek GD, Poisat P, Sono T, Schultz HB (2008). Human Resources Management. (7th ed.). Cape Town: Oxford.

Ngo, H., Foley, S., \& Loi, R. (2009). Family friendly work practices, organizational climate, and firm performance: A study of multinational corporations in Hong Kong. J. Organ. Behav. 30:665-680.

NNSDO. (2005). Validating research instruments. Available at https://www.nnsdo.org/dmdocuments/ValidatingResearchlnstruments .pdf. [Retrieved July 1, 2011].

Pillay R (2009). Work satisfaction of professional nurses in South Africa: a comparative analysis of the public and private sectors. Hum. Resour. Health 7(15):1-10.
Pundit P (2006). Work satisfaction among nurses in South Africa. A comparative analysis between public and private organisations. Unpublished MBA degree thesis. University of Cape Town.

Rao TB (2010). Research Methodology. ( ${ }^{\text {rd }}$ ed.). New Delhi: Paras.

Robbins SP, Judge TA, Odendaal A, Roodt G (2009). Organisational Behaviour. Global and Southern African Perspectives. Cape Town: Pearson.

Rowe AK, de Savigny D, Lanata CF, Victoria CG (2005). How can we achieve and maintain high-quality performance of health workers in low-resource settings? Lancet 366:1026-1035.

Sheldon KM, Bettencourt BA (2002). Psychological need-satisfaction and subjective well-being within social groups. Br. J. Soc. Psychol. 41:25-38.

Smit JA (2006). The influence of coping and stressors on burnout and compassion fatigue among health care professionals. Unpublished $\mathrm{Ph} . \mathrm{D}$ degree thesis. University of Free State.

Srivastava A, Bartol KM, Locke EA (2006). Empowering leadership in management teams: Effects on knowledge sharing, efficacy, and performance. Acad. Manag. J. 49(6):1239-1251.

Stamps PL, Piemont EB, Slavitt DB, Haase AM (1978). Measurement of Work Satisfaction among Health Professionals. Med. Care 16(4).

Strydom A, Roodt G (2006). Developing a predictive model of subjective organisational culture. South Afr. J. Ind. Psychol. 32(4):15-25.

Thomas LS, Valli A (2006). Levels of occupational stress in doctors working in a South African public-sector hospital. South Afr. Med. J. 96(11):1162-1168.

Van der Ploeg E, Kleber RJ (2003). Acute and chronic job stressors among ambulance personnel: predictors of health symptoms. Occup. Environ. Med. 60(Suppl 1):i40-i46.

Webb JR (2002). Understanding and designing market research. London: Thomson Learning.

Welman C, Kruger F, Mitchell B (2005). Research methodology. ( $3^{\text {rd }}$ ed.). Cape Town: Oxford.

$\mathrm{Xu}$ J, Thomas HC (2011). How can leaders achieve high employee engagement? Leadersh. Organ. Dev. J. 32(4):399-416.

Zikmund WG, Babin BJ, Carr JC, Griffin M (2010). Business Research Methods. ( $8^{\text {th }}$ ed.). Canada: South-Western. 